\title{
Covering hay in the irrigated Sonoran Desert decreases heat damage
}

\author{
Juan N. Guerrero \\ Martin I. Lopez \\ Miguel Cervantes \\ $\nabla$
}

Hay stored for prolonged periods of time decreases in value for feeding livestock. The irrigated Sonoran Desert of southeastern California and western Arizona is the hottest inhabited part of the United States, with summer temperatures routinely exceeding $100^{\circ} \mathrm{F}$ from May through October. We evaluated the effects of three methods of hay storage there during the summer: uncovered, under a roof and under a tarp. After 21 weeks, hay that was protected from summer solar radiation, either by the use of barn storage or plastic tarps, had more digestible content.

W ith temperatures routinely exceeding $100^{\circ} \mathrm{F}$ from May through October, the irrigated Sonoran Desert of southeastern California and western Arizona is the hottest inhabited part of the United States. In the Imperial Valley (part of this desert) mean annual rainfall is just 2.85 inches. Due to the scarcity of rainfall, baled hay is commonly stored unprotected along roadsides. If stored for prolonged periods, it can become extremely dry and increase in both neutral detergent fiber (NDF) and acid detergent fiber (ADF) (Rotz and Muck 1994). With less than $10 \%$ moisture, hay becomes brittle and unpalatable to livestock. As NDF and ADF increase, hay quality decreases - and consequently so do hay prices.

In addition, hay stored at temperatures greater than $100^{\circ} \mathrm{F}$ for prolonged periods of time may form Maillard products (Pitt 1990), condensates formed from nonenzymatic reactions of sugars and amino acids. Maillard products possess many of the chemical properties of lignin, which is highly indigestible. The formation of Maillard

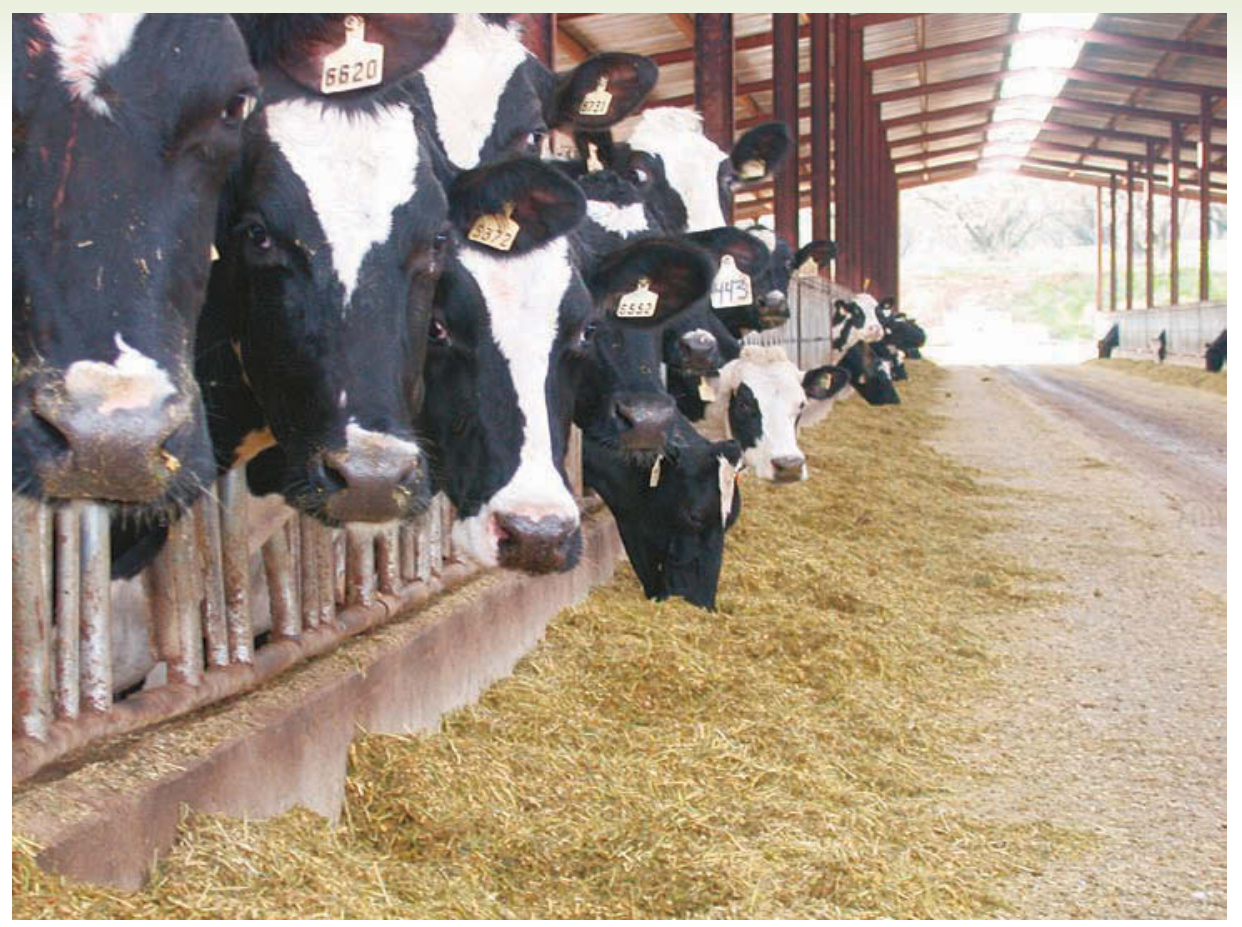

Alfalfa hay is a key ingredient in dairy cattle feed. Exposure to sun and heat can degrade the nutritional quality of hay and reduce its price.

products in hay is indicative of decreased protein and dry matter $(\mathrm{DM})$ digestibility (Thomas et al. 1982) and consequently reduced livestock performance. Maillard products may be quantified in forages by measuring nitrogen in the ADF fraction, also known as acid detergent insoluble nitrogen (ADIN) (Goering et al. 1972). Maillard products may be part of the ADF fraction.

Alfalfa hay stored during the Sonoran Desert summer loses DM and has increased NDF, ADF and ADIN (Guerrero and Winans 1999). The objective of our study was to quantify the digestibility attributes of summer-stored alfalfa hay in the Sonoran Desert under three storage treatments. In collaboration with the Autonomous University of Baja California (UABC) in nearby Mexicali, Mexico, at the end of the 21-week storage period we fed the treated hay to fistulated Holstein steers at the UABC agriculture school.

\section{Hay storage and digestibility}

Alfalfa hay was baled on June 2, 1998, at the UC Desert Research and
Extension Center (DREC) in Holtville in the Sonoran Desert. Individual bales were randomly allocated to three storage treatments: (1) uncovered, (2) under a roof and (3) covered with a plastic tarp. We allocated about 2 tons of baled alfalfa hay per treatment, and the hay was stored for 21 weeks. Daily climatological data was recorded from the DREC weather station. Biweekly (at 3 p.m.) during the 21-week storage period, we took four hay samples of about 30 grams per treatment using a hay-coring device and recorded bale temperature and moisture. Hay samples were ground using a 1-millimeter screen, and were composited and placed in airtight plastic bags that were kept at a constant $72^{\circ} \mathrm{F}$. At the end of the 21-week storage period, the ground alfalfa hay samples were evaluated for DM, NDF, ADF and ADIN. All composited hay samples were analyzed in triplicate and mean values reported.

The experimental hay was then transported about 30 miles southeast to the UABC agriculture school. To evaluate its digestibility attributes, we used 


\begin{tabular}{|c|c|c|c|c|c|}
\hline \multirow[b]{2}{*}{ Chemical attributes } & \multirow{2}{*}{$\begin{array}{c}\text { Initial } \\
\text { conditions* }\end{array}$} & \multicolumn{3}{|c|}{ Aug. 25, 1998} & \multirow[b]{2}{*}{ SE } \\
\hline & & Uncoveredt & Roofed & Tarped & \\
\hline \multicolumn{6}{|c|}{ 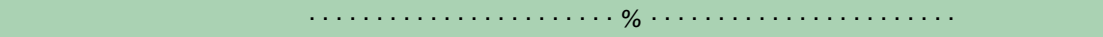 } \\
\hline DM & 86.0ał & $94.0 \mathrm{~b}$ & $92.0 \mathrm{~b}$ & $93.0 \mathrm{~b}$ & 0.76 \\
\hline ADIN, DM & $0.10 \mathrm{a}$ & $0.51 \mathrm{~b}$ & $0.51 b$ & $0.56 b$ & 0.02 \\
\hline N, DM & 3.90 & 3.95 & 3.76 & 3.72 & 0.54 \\
\hline ADIN/N & $2.59 c$ & $12.79 b$ & $13.56 \mathrm{ab}$ & $15.56 a$ & 0.64 \\
\hline NDF & $33.98 \mathrm{ab}$ & $32.68 \mathrm{~b}$ & 36.89a & $34.50 \mathrm{ab}$ & 1.73 \\
\hline ADF & $24.00 \mathrm{a}$ & $19.63 b$ & $26.74 a$ & 23.81a & 2.54 \\
\hline Bale temperature§ & $79.70 \mathrm{c}$ & $107.96 a$ & $98.42 b$ & $107.06 a$ & 2.69 \\
\hline \multicolumn{6}{|c|}{ * Hay baled June 2,$1998 ; 10$ randomly selected bales prior to treatment allocation. } \\
\hline \multicolumn{6}{|c|}{$\begin{array}{l}\text { Uncovered = stored outside uncovered; roofed = stored outside under a roof and protected from sunlight; } \\
\text { tarped = stored outside covered with plastic tarp. }\end{array}$} \\
\hline \multicolumn{6}{|c|}{$\neq$ Means in a row with different letters differ $(P<0.05)$, paired $t$-test. } \\
\hline$\S$ At 3 p.m. & & & & & \\
\hline
\end{tabular}

three fistulated (rumen, ileum and duodenum) 330-pound Holstein steers. (A fistula is a passage, made by a veterinarian, from the internal organs to the exterior of the body. The rumen, ileum and duodenum are parts of the digestive tract.) The fistulated steers were offered unlimited access to experimental hay and fed twice a day ( 7 a.m. and 5 p.m.) over three rotational 14-day periods: a 10-day adaptation period and a 4-day sampling period. Steers consumed only experimental hay during the 4-day sampling periods. To determine DM digestibility, 15 grams of chromium oxide per day were administered to the steers in ground alfalfa. Since chromium oxide is indigestible, it acts as a digestibility marker. By placing a known amount in the feed and then measuring the concentration in the feces, indigestability can be calculated.

During the 4 sampling days, ruminal, ileal and duodenal digestive fluids (digesta) were placed into 500-milliliter (ml) plastic containers. Sampling times were 7:30 a.m. and 1:30 p.m. on day 11, 9 a.m. and 3 p.m. on day 12, 10:30 a.m. and 5:30 p.m. on day 13, and 12 p.m. and 7 p.m. on day 14. Digesta samples were lyophilized, ground and stored. Fecal samples were dried in a forcedair oven at $122^{\circ} \mathrm{F}$ for 72 hours, ground and stored. On day 14, $500 \mathrm{ml}$ of rumen liquor (the liquid fraction of ruminal contents) was collected from each animal and the samples were centrifuged to isolate rumen bacteria. Using the rumen liquor, we measured purine content to calculate bacterial protein; bacterial protein content could then be discounted from the alfalfa protein di- gestibility determinations. Digesta and fecal samples were subjected to the following chemical evaluations: DM, crude protein, NDF, ADF and chromium (by atomic absorption spectroscopy). The chemical attributes of the stored alfalfa hay were compared with paired $t$-tests. The chemical attributes of digesta and fecal samples were compared using a $3 \times 3$ Latin square design.

\section{Sample moisture and temperature}

The summer of 1998 was cool by Sonoran Desert standards, with temperatures at DREC consistently lower than long-term average temperatures (fig. 1, page 255). Our September and October hay samples were discarded because they became moldy due to an electrical malfunction in the storage area. Consequently, we report the results of 11 weeks of hay storage during the Sonoran Desert summer.

When the experimental hay was baled on June 2, 1998, its moisture was $14 \%$. By late August, dry matter (DM) for the uncovered (T1), under a roof (T2) and covered with a plastic tarp (T3) samples had increased 6\%,8\% and $7 \%$, respectively (table 1 ). Guerrero and Winans (1999) reported similar bale moisture for alfalfa hay treated similarly. Extremely dry hay is brittle and, when ground and added to feedlot or dairy cattle diets, often turns into the consistency of flour. These "fines" are detrimental to cattle health and to the overall digestibility of the diet.

At baling, mean bale temperatures were $80^{\circ} \mathrm{F}$. After 11 weeks of storage at DREC, bale temperatures for the

\section{Glossary}

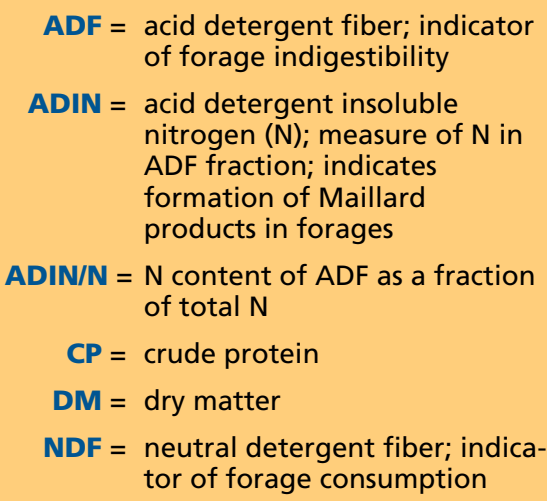
tor of forage consumption

uncovered, roofed and plastic-tarped hays were about $108^{\circ} \mathrm{F}, 98^{\circ} \mathrm{F}$ and $107^{\circ} \mathrm{F}$, respectively (table 1). Guerrero and Winans (1999) reported similar temperatures for alfalfa hay treated similarly. Hay stored at temperatures greater than $95^{\circ} \mathrm{F}$ for prolonged periods decreases in nutritive value (Goering et al. 1973; Yu and Veira 1977; Thomas et al. 1982; Pitt 1990).

\section{Heat affects hay quality}

The initial NDF and ADF contents of our experimental hays were $33.98 \%$ and $24.00 \%$, respectively (table 1 ). The ADF content of the uncovered hay decreased significantly after 11 weeks, but it increased in the roofed and plastic-tarped samples; for NDF content, the uncovered

\section{We recommend that hay bales be} protected from excessive heat during summer in the irrigated Sonoran Desert.

hay basically remained the same but increased significantly in the roofed and plastic-tarped samples. Rotz and Muck (1994) reported that after prolonged storage, hay desiccation and loss of soluble carbohydrates result in NDF and ADF increases. In a similar experiment, Guerrero and Winans (1999) reported increases $(P<0.05)$ of both NDF and ADF after 11 weeks of storage. However, after 11 weeks of storage, summer temperatures during 1998 did not affect $(P>0.10)$ NDF or ADF in our current experiment as adversely as in our previous experiment (Guerrero and Winans 1999).

Goering et al. (1972) suggested that forages with greater than $14 \% \mathrm{ADIN} / \mathrm{N}$ 

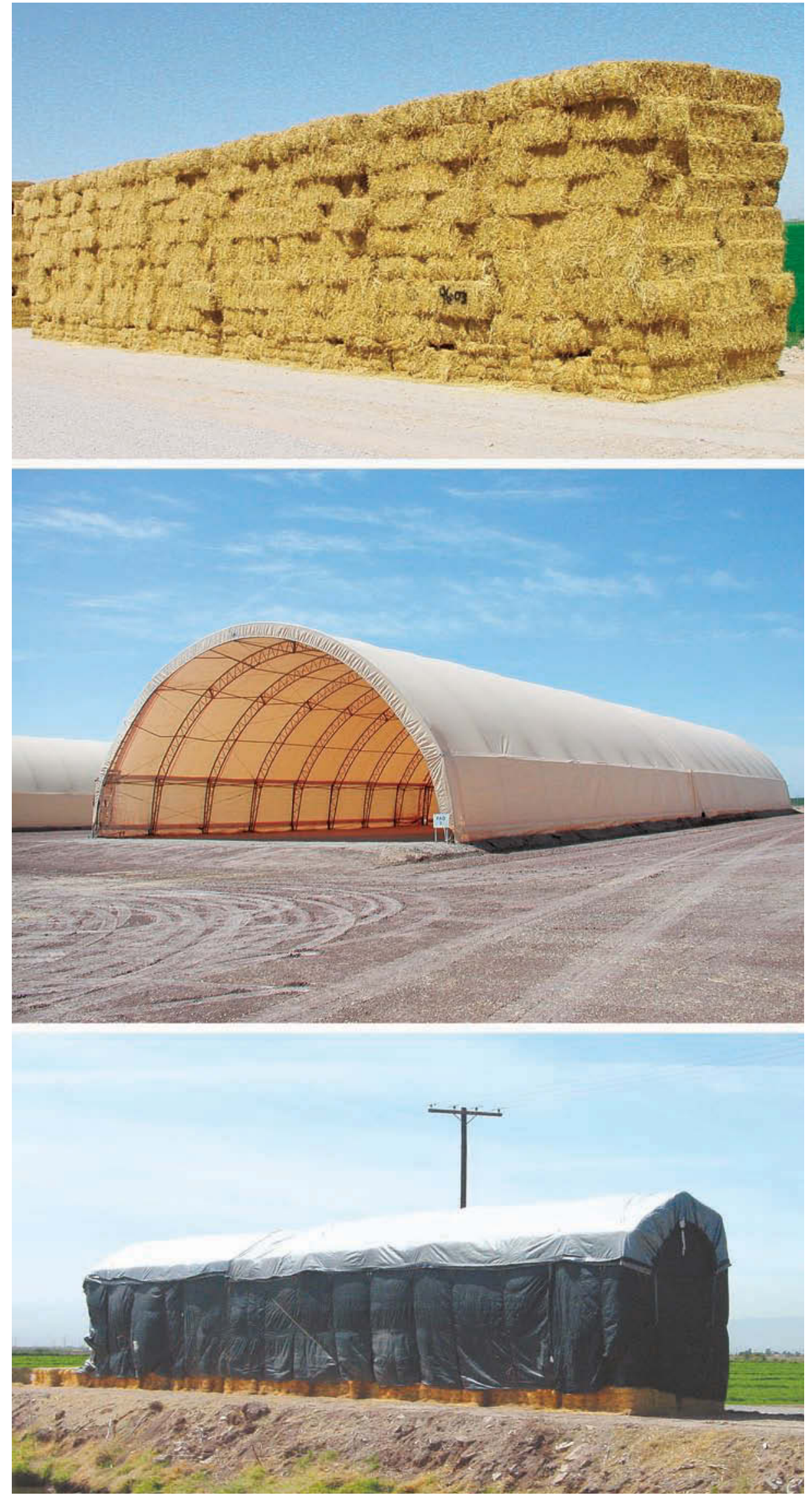

Top, alfalfa hay is normally stored unprotected along ditch banks in the Sonoran Desert; middle, hay can be stored outside but protected from rain and sunshine; bottom, tarped hay. (nitrogen content of ADF as a fraction of total N) may be considered heatdamaged. In our experiment, ADIN/N increased significantly $(P<0.05)$ under all treatments, suggesting the formation of Maillard products (table 1). After 11 weeks of hay storage in the irrigated Sonoran Desert, Guerrero and Winans (1999) had ADIN/N levels of $13 \%, 17 \%$ and $17 \%$ for similar storage treatments. The previous baledhay storage trial was done during the summer of 1993, which was warmer than during our 1998 trial, with mean monthly maximum temperatures from June through October of $114^{\circ} \mathrm{F}, 113^{\circ} \mathrm{F}$, $118^{\circ} \mathrm{F}, 112^{\circ} \mathrm{F}$ and $105^{\circ} \mathrm{F}$, respectively.

We regressed climatological data on the amount of heat damage in the stored hays (table 2). Initially, by means of correlation analyses, we evaluated the relationships between cumulative degree-hours greater than $95^{\circ} \mathrm{F}$, bale moisture, ambient relative humidity, bale temperature, solar radiation, NDF, ADF, ADIN, ADIN/N and lignin. Variables that were highly correlated $(>0.80)$ were not selected for the regression analyses. We used a backward elimination procedure $(\alpha<0.10)$ to eliminate insignificant regressors.

Summer heat in the Sonoran Desert affected hay quality for the uncovered and plastic-tarped hays; these storage treatments had warmer bale temperatures than those under a roof (table 1). For the uncovered hay, bale temperatures $\left(\mathrm{X}_{1}\right)$ accounted for $62 \%$ of the total variability in ADIN/N percentage. For the plastic-tarped hay, cumulative degree-hours greater than $95^{\circ} \mathrm{F}\left(\mathrm{X}_{3}\right)$ accounted for $70 \%$ of the total variability in ADIN/N percentage. Uncovered bales were exposed to direct sunlight while plastic-tarped bales were in full sunlight but protected from direct solar radiation. The independent variables in table 2 are both different temperature measures: $X_{1}$ is bale temperature and 
$X_{3}$ is a measure of cumulative ambient temperature. Comparing the uncovered and plastic-tarped $\beta_{1}$ values shows that the effect of direct solar radiation on bale temperatures was 55 times greater on ADIN/N (a measure of total protein unavailability). Evidently the interaction of both temperature and solar radiation in the Sonoran Desert summer affected hay quality.

\section{Reduced digestibility}

Thomas et al. (1982) suggested that heat-damaged forages have both increased DM and decreased protein digestibility. In our experiment with the fistulated cattle, the total gastrointestinaltract digestibility of crude protein and DM was greater $(P<0.05)$ for the roofed and plastic-tarped hays than for the uncovered hay (table 3). While both were subject to high ambient temperatures, the roofed bales were not exposed to the radiant energy of direct sunlight while the plastic-tarped bales were. The tarps used in this study were blue while those used by Guerrero and Winans (1999) were grey. The effects of tarp color on the

TABLE 2. Regression analyses of environmental factors affecting heat damage of alfalfa hay stored during summer, irrigated Sonoran Desert

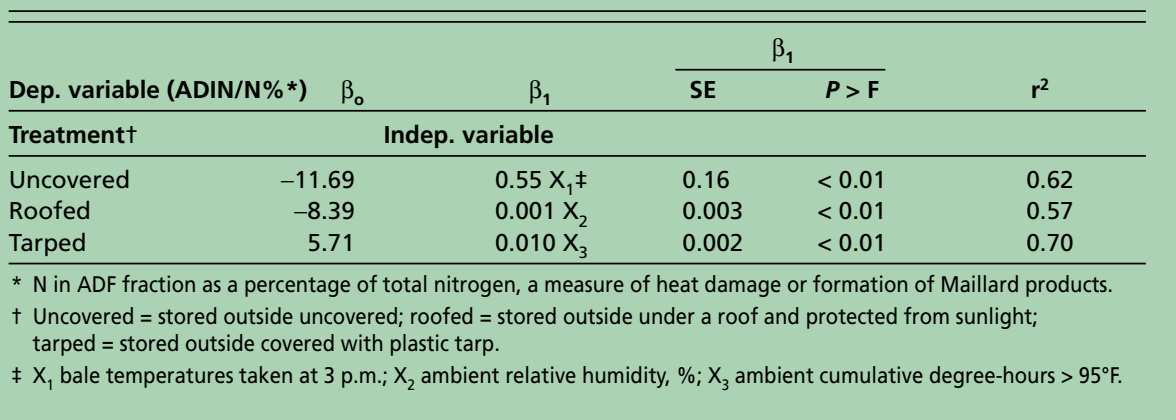

quality of hay stored under extreme heat and radiant energy are not known.

Based on previous research and our current experiments, we recommend that hay bales be protected from excessive heat during summer in the irrigated Sonoran Desert, because unprotected alfalfa hay bales become heat-damaged and thereby decreased in overall digestibility.

\section{J.N. Guerrero is Cooperative Extension} Area Livestock Advisor, and M.I. Lopez is Cooperative Extension Lab Assistant, both stationed at the UC Desert Research and Extension Center, Holtville; and M. Cervantes is Professor of Animal Science, Autonomous University of Baja California (UABC), Mexicali. This study was part of Lopez's doctoral thesis at UABC.

\section{References}

Goering HK, Gordon $\mathrm{CH}$, Hemken RW, et al. 1972. Analytical estimates of nitrogen digestibility in heat damaged forages. J Dairy Sci 55:1275-80.

Goering HK, Van Soest PJ, Hemken RW. 1973. Relative susceptibility of forages to heat damage as affected by moisture, temperature, and pH. J Dairy Sci 56:137-43.

Guerrero JN, Winans SS. 1999. Desert heat degrades quality of stored alfalfa hay. $\mathrm{Cal} \mathrm{Ag}$ 53(1):37-40.

Pitt RE. 1990. Silage and hay preservation. NRAES-5. NE Reg Agric Eng Serv, Ithaca, NY

Rotz CA, Muck RE. 1994. Changes in forage quality during harvest and storage. In: Fahey GC, et al. (eds.). Forage Quality, Evaluation, and Utilization. ASA, CSSA, and SSSA, Madison, WI. p 828-68.

Thomas JW, Yu Y, Middleton T, Stallings C. 1982. Estimations of protein damage. In: Owens FN (ed.). Protein Requirements for Cattle. Oklahoma State Univ. MP 109. p 81-98.

Yu Y, Veira DM. 1977. Effect of artificial heating of alfalfa haylage on chemical composition and sheep performance. J Ani Sci 44:1112-8.

\begin{tabular}{|c|c|c|c|c|}
\hline \multicolumn{5}{|c|}{$\begin{array}{l}\text { TABLE 3. Mean digestibility of nutrients by } 330 \mathrm{lb} \text {. Holstein steers } \\
\text { consuming alfalfa hay stored from June to November 1998, } \\
\text { irrigated Sonoran Desert }\end{array}$} \\
\hline & \multicolumn{3}{|c|}{ Treatment* } & \multirow[b]{2}{*}{ SE } \\
\hline & Uncovered & Roofed & Tarped & \\
\hline \multicolumn{5}{|c|}{ Consumption, kg/day } \\
\hline DM & 4.07 & 4.11 & 3.60 & 0.14 \\
\hline NDF\% & 1.30 & 1.42 & 1.25 & 0.08 \\
\hline ADF\% & $0.92 \mathrm{bt}$ & $1.08 \mathrm{ab}$ & $0.88 \mathrm{~b}$ & 0.11 \\
\hline $\mathrm{CP}$ & $0.89 a$ & $0.81 \mathrm{~b}$ & $0.84 a b$ & 0.03 \\
\hline \multicolumn{5}{|c|}{ Ruminal digestion, \% DM consumption } \\
\hline DM & $49.5 b$ & $59.2 a$ & $53.4 \mathrm{ab}$ & 2.1 \\
\hline NDF\% & $40.7 \mathrm{ab}$ & $48.0 a$ & $32.4 b$ & 6.0 \\
\hline ADF\% & $35.7 \mathrm{ab}$ & $45.8 a$ & $25.5 b$ & 7.0 \\
\hline $\mathrm{CP}$ & $46.9 \mathrm{~b}$ & $58.0 a$ & $55.0 \mathrm{a}$ & 2.6 \\
\hline \multicolumn{5}{|c|}{ Total digestion, $\%$ of consumption } \\
\hline DM & $59.5 c$ & $66.2 a$ & $64.7 b$ & 0.7 \\
\hline NDF\% & $39.2 b$ & $53.2 a$ & $47.2 \mathrm{ab}$ & 4.2 \\
\hline ADF\% & $33.0 \mathrm{c}$ & $47.5 a$ & $37.9 b$ & 2.0 \\
\hline $\mathrm{CP}$ & $76.7 b$ & $81.2 a$ & $80.6 a$ & 0.3 \\
\hline \multicolumn{5}{|c|}{$\begin{array}{l}\text { * Uncovered = stored outside uncovered; roofed = stored outside under a roof and } \\
\text { protected from sunlight; tarped = stored outside covered with plastic tarp. }\end{array}$} \\
\hline † Means in & ferent letters & er, $(P<0.05)$ & ed $t$-test. & \\
\hline
\end{tabular}

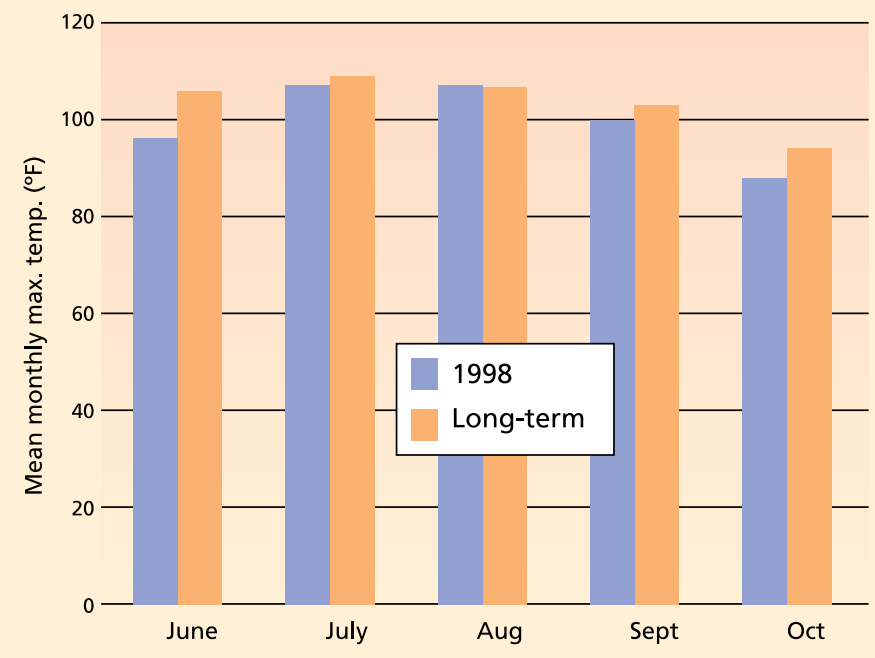

Fig. 1. Mean monthly maximum temperatures at UC Desert Research and Extension Center. The long-term mean was calculated over a span of 80 years. 